\title{
Correction to: Revisiting the evidence for genotoxicity of acrylamide (AA), key to risk assessment of dietary AA exposure
}

\section{Gerhard Eisenbrand ${ }^{1}[$}

Published online: 16 September 2020

(c) The Author(s) 2020

\section{Correction to: Archives of Toxicology (2020) 94:2939-2950 https://doi.org/10.1007/s00204-020-02794-3}

Unfortunately, the following errors occurred during the production process, compromising text understandability:

1. page 2945 , the subheading after the second paragraph should read:

Taken together, the totality of the above described in-vitro evidence compellingly reveals...

2. page 2946, the last sentence of the second paragraph should read:

Formation of urinary MAs and of $N^{7}$-GA-Gua DNA adducts in liver, kidney and lung was measured $16 \mathrm{~h}$ after application, a time point where a previous pilot experiment had shown maximal $N^{7}$-GA-Gua DNA concentration to occur. The separate subheading: $\mathbf{N}^{7}$-GA-Gua DNA concentration to occur is to be deleted.

\section{Potential conflicts of interest:}

The author receives honoraria for scientific consultation as a member of

The Scientific Committee of the Institute For Scientific Information On Coffee, ISIC, van Boetzelaerlaan 212581 AA The Hague the Netherlands

The original article can be found online at https://doi.org/10.1007/ s00204-020-02794-3.

Gerhard Eisenbrand

eisenbra@rhrk.uni-kl.de

1 University of Kaiserslautern, Germany (Retired), Kühler

Grund 48/1, 69126 Heidelberg, Germany
The Expert Panel of the Flavor and Extract Manufacturers Association, Washington DC, USA;

The Genotoxicity Adjunct Team of the Research Institute for Fragrance Materials, Woodcliff Lake NJ, USA;

The Food Safety Science Advisory Panel, Fonterra Research and Development, Palmerston North, NZ.

Publisher's Note Springer Nature remains neutral with regard to jurisdictional claims in published maps and institutional affiliations. 